\title{
Trends and Varieties in Late Caddo and Historic Caddo Fine Ware Pottery Types in the Upper Neches River Basin
}

Timothy K. Perttula

Heritage Research Center, Stephen F. Austin State University

Follow this and additional works at: https://scholarworks.sfasu.edu/ita

Part of the American Material Culture Commons, Archaeological Anthropology Commons, Environmental Studies Commons, Other American Studies Commons, Other Arts and Humanities Commons, Other History of Art, Architecture, and Archaeology Commons, and the United States History Commons

Tell us how this article helped you.

This Article is brought to you for free and open access by the Center for Regional Heritage Research at SFA ScholarWorks. It has been accepted for inclusion in Index of Texas Archaeology: Open Access Gray Literature from the Lone Star State by an authorized editor of SFA ScholarWorks. For more information, please contact cdsscholarworks@sfasu.edu. 


\section{Trends and Varieties in Late Caddo and Historic Caddo Fine Ware Pottery Types in the Upper Neches River Basin}

\section{Creative Commons License}

\section{(c) (1) (8)}

This work is licensed under a Creative Commons Attribution-NonCommercial 4.0 International License 


\title{
Trends and Varieties in Late Caddo and Historic Caddo Fine Ware Pottery Types in the Upper Neches River Basin
}

\author{
Timothy K. Perttula
}

One of the goals of recent archaeological research investigations in the upper Neches River valley in East Texas is to better understand the temporal and stylistic character of the post-A.D. 1400/1450 Frankston and Allen phase Caddo ceramic assemblages found in this area. From this will hopefully arisc a better understanding of the settlement history of Caddo peoples living here.

This research has involved a detailed examination of 278 vessels from burials on seven sites in the collections at the Texas Archeological Research Laboratury (TARL), 31 vessels from burials at 41 AN38 (Perttula et al. 2007), and a review of other vessel data ( $n=321$ vessels) from several other sites and diverse collections, both at TARL, in private collections, and in archaeological excavations (sce Perttula 2006; Shafer 1981). In total, I have compiled a data base of 630 vessels from 35 different sites in Anderson, Cherokee, Henderson, and Smith countics, Texas.

The basic composition of the Caddo vessel assemblage from upper Neches River burial sites includes fine wares $(73.3 \%)$, decorated utility wares $(14.9 \%)$, and a significant proportion of plain ware vessels $(11.8 \%)$. The principal fine wares are Poynor Engraved bowls and carinated bowls $(n=229,49.6 \%$ of the fine wares), Patton Engraved ( $n=63,13.4 \%)$, Hood Engraved ( $n=56,12.1 \%$ ) - a newly named type that comprises effigy ware vessels decorated with broad horizontal engraved lines-and Hume Engraved $(n=54,11.7 \%)$. Among the utility wares, the major typcs include Bullard Brushed $(n=21)$, Killough Pinched ( $n=20)$, Maydellc Incised $(n=11)$, punctated jars $(n=9)$, and brushed-punctated jars $(n=8)$. Must of the plain wares are simple buwls $(n=29)$, carinated bowls $(n=23)$, and several forms of bottles $(n=16)$.

For the moment, I have focused in detail on the fine wares from the ceranic vessel data base, primarily because they are ubiquitous on upper Neches River Caddo sites and because the stylistic diversity in the fine wares is amenable to a more refined consideration of stylistic and temporal changes in these ceramic assemblages. This pursuit includes the recognition of distinct stylistic motifs and elements in the fine wares; attempting to identify varieties of the fine ware types that have spatial distributions and an adequate site representation; and examining the temporal implications of these varieties. Previous vessel and sherd seriation analyses (Klcinschmidt 1982; Perttula 2007) have already established that Patton Engraved is the youngest of the fine ware types in the upper Neches River (and it is commonly found in association with late $17^{\text {th }}$ and carly $18^{\text {th }}$ century European trade goods; see Cole 1975), with Hume Engraved, Hood Engraved, and Poynor Engraved having begun to be made around ca. A.D. 1400 or so. Hume Engraved is most common apparently in post-A.D, 1650 Allen phase contexts, while Poynor Engraved is primarily a Frankston phase (ca. A.D. 1400-1650) typc.

Although I have recognized at lcast 30 Poynor Engraved bowl and carinated bowl rim stylistic motifs-including several from $41 \mathrm{AN} 38$ that may be amongst the carliest motifs-five new varietics represent more than $73 \%$ of the Poynor Engraved vessels in the upper Neches River basin. These include varieties Blackburn, Cook, Freeman, Hood, and Lang (Figure 1); var. Hood is the most common (see Figure 1e). In the present vessel assemblages, I have also defined three varieties of Hood Engraved (var. Cook, var. Hood, and var. Allen), two varieties of Hume Engraved and a third unspecified variety, that is, a variety in search of a name (Figure 2e-g) (var. Allen and var. Hume), and four varieties of Patton Engraved (var. Allen, Fair, Freeman, and Patton) (Figure 2a-d). Patton Engraved, var. Freeman (see Figure 2c) is the dominant known variety of this type.

Some progress has been made in discerning temporal changes in the finc ware varieties beyond 
Table 1. Ceramic Vessel Database from the upper Neches River valley in East Texas.

\begin{tabular}{|c|c|c|c|}
\hline Wares & No. of vessels & No. of sites & Percentage \\
\hline \multicolumn{4}{|l|}{ Utility Wares } \\
\hline Killough Pinched & 20 & 10 & 3.2 \\
\hline Bullard Brushed & 21 & 11 & 3.3 \\
\hline Maydelle Incised & 11 & 7 & 1.8 \\
\hline Punctated jar & 9 & 3 & 1.4 \\
\hline Punctated-appliqued jar & 1 & 1 & 0.2 \\
\hline La Rue Neck Banded & 1 & 1 & 0.2 \\
\hline Incised Jar & 5 & 3 & 0.8 \\
\hline Brushed-incised-punctated jar & 1 & 1 & 0.2 \\
\hline Brushed-punctated jar & 8 & 4 & 1.3 \\
\hline Brushed-pinched-appliqued jar & 1 & 1 & 0.2 \\
\hline Brushed bowl & 5 & 4 & 0.8 \\
\hline Poynor Brushed & 3 & 2 & 0.5 \\
\hline Brushed-pinched jar & 2 & 1 & 0.3 \\
\hline Appliqued jar & 1 & 1 & 0.2 \\
\hline Brushed-incised jar & 3 & 2 & 0.5 \\
\hline Incised-punctated jar & 1 & 1 & 0.2 \\
\hline Incised-pinched jar & 1 & 1 & 0.2 \\
\hline Subtotal & 94 & 14.9 & \\
\hline \multicolumn{4}{|l|}{ Plain Wares } \\
\hline Plain bowl & 29 & 14 & 4.6 \\
\hline Plain jar & 6 & 4 & 1.0 \\
\hline Plain carinated bowl & 23 & 9 & 3.7 \\
\hline Plain bottle & 16 & 7 & 2.5 \\
\hline Subtotal & 74 & 11.8 & \\
\hline \multicolumn{4}{|l|}{ Fine wares } \\
\hline Simms Engraved, var. Darco & 3 & 1 & 0.5 \\
\hline Hume Engraved bottles/bowls & $50 / 4$ & 19 & 8.6 \\
\hline Garland Engraved (?) & 1 & 1 & 0.2 \\
\hline Unidentified engraved bottle & 3 & 2 & 0.5 \\
\hline Poynor Engraved bottle & 42 & 15 & 6.7 \\
\hline Poynor Engraved & 229 & 32 & 36.3 \\
\hline Hood Engraved & 56 & 22 & 8.9 \\
\hline Taylor Engraved & 6 & 5 & 1.0 \\
\hline Patton Engraved & 63 & 10 & 10.0 \\
\hline Horizontal engraved bowl & 1 & 1 & 0.2 \\
\hline Natchitoches Engraved & 1 & 1 & 0.2 \\
\hline Engraved-punctated bowl & 1 & 1 & 0.2 \\
\hline Red-slipped bowl & 2 & 2 & 0.3 \\
\hline Subiotal & 462 & 73.3 & \\
\hline
\end{tabular}




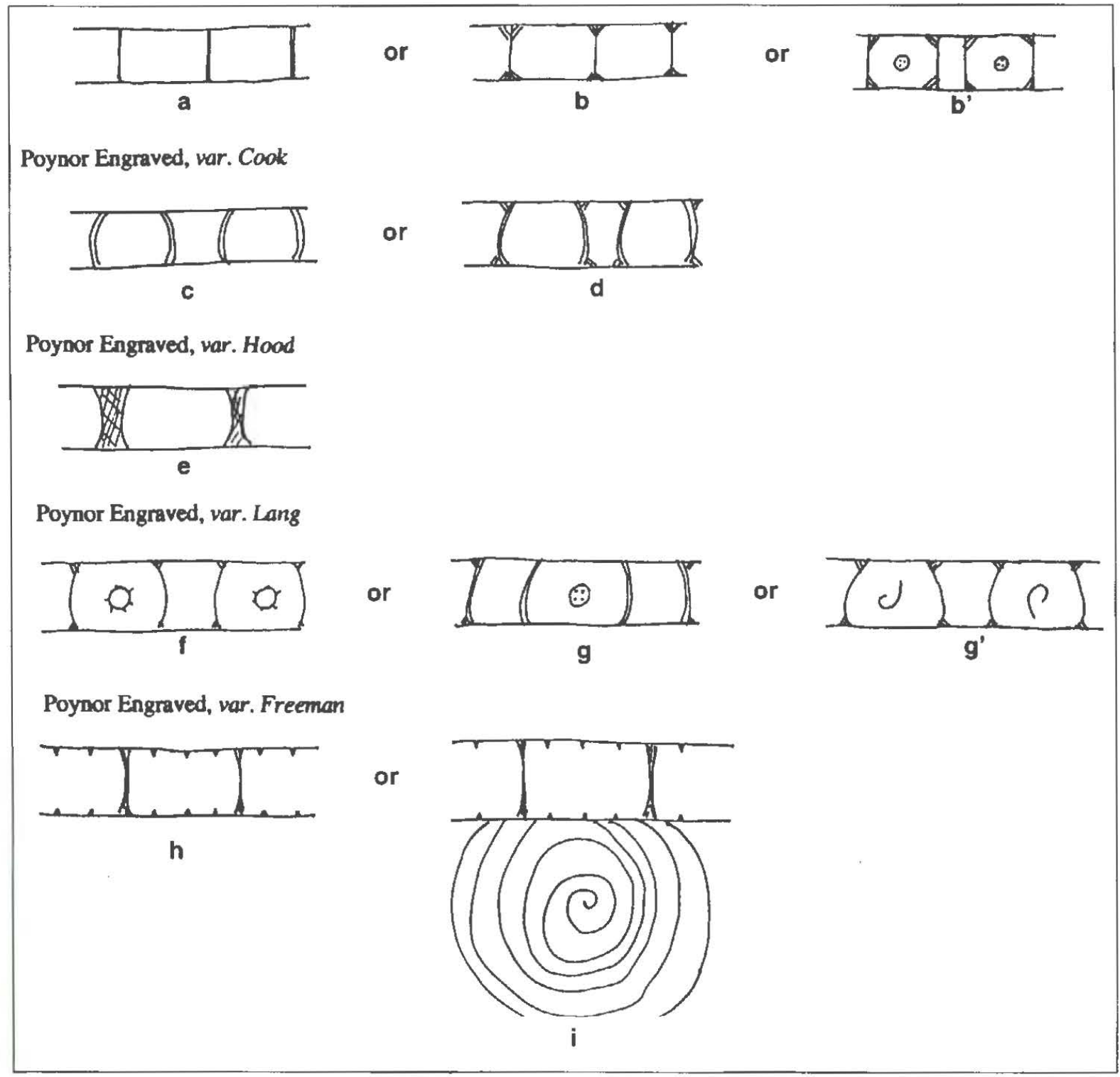

Figure 1. Varieties of Poynor Engraved in the upper Neches River basin.

the basic distinction bctween the earlier Poynor Engraved varieties and the later Patton Engraved varieties. First, Poynor Engraved, var. Freeman appears to be the latest variety of the Poynor Engraved type, and the simple addition of concentric circles on the body (see Figure 1i) on this variety, and then the addition of ticked marks to body concentric circles (sce Figure 2c), suggests a clear stylistic link betwcen Poynor Engraved, var. Freeman and Patton Engraved, var. Freeman. This further suggests that Patton Engraved, var. Freeman is the earliest of the defined Patton Engraved varieties. This varicty of Patton Engraved is the dominant one $(39.3 \%)$ at the Richard Patton site (41AN26), along with var. Patton (28.6\%), var. Fair (14.3\%), and var. Allen
$(14.3 \%)$. Based on lower proportions of var. Freeman and var. Patton at the Jim Allen site (4ICE12), but higher proportions of var. Allen $(41.2 \%)$ and several unspecified varietics, it is suspected that var. Allen is a later Patton Engraved variety.

Hood Engraved, var. Allen is found in association with Patton Engraved, and is an Allen phase diagnostic. This effigy vcsscl form includes tail riders. The other varieties of Hood Engraved have effigy heads and tab tails-as well as horizontal engraved lines, with var. Cook also having engraved pendant triangle elements-and arc found in Frankston phase temporal contexts. Hume Engraved, var. Allen and var. Hume are found primarily in Allen phase contexts or late Frankston phase contexts. 
Patton Engraved, var. Allen

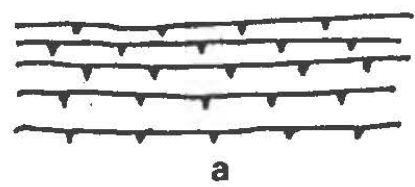

Patton Engraved, var. Palton

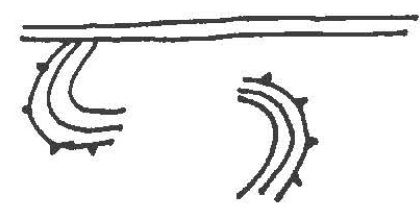

b

Patton Engraved, var. Freeman

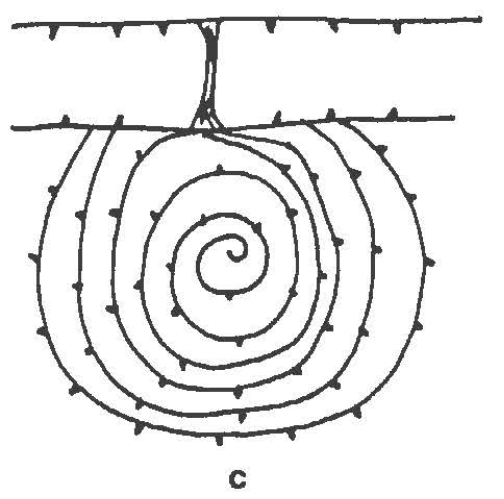

Patton Engraved, var. Fair
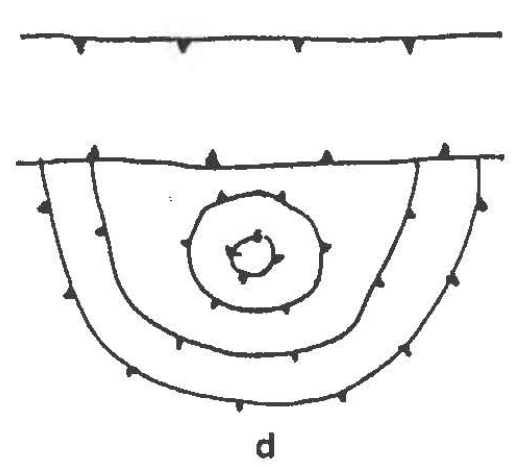

d
Hume Engraved, var. Hume

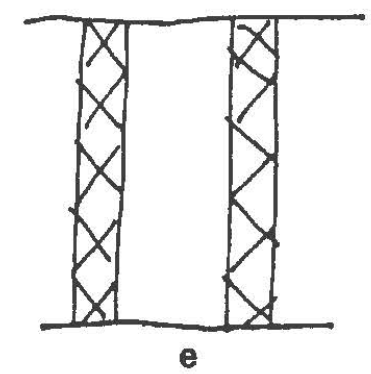

Hume Engraved, var. Allen

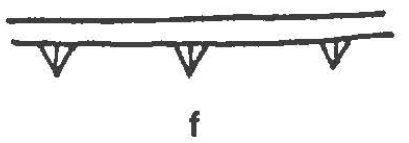

Hume Engraved, var. unspecified

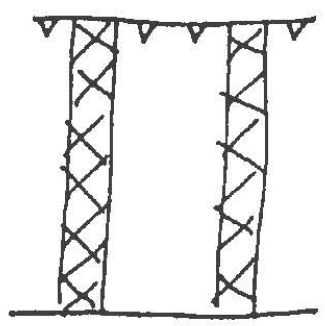

g

Figure 2. Defined varieties of Hume Engraved and Patton Engraved in the upper Neches River basin. 


\section{REFERENCES CITED}

Cole. N. M.

1975 Early Historic Caddoan Mortuary Practices in the Upper Neches Drainage, East Texas. Master's thesis. Department of Anthropology. The Unjversity of Texas at Austin.

Kleinschmidt, U. K. W.

1982 Review and Analysis of the A. C. Saunders Site, 41 AN19, Anderson County, Texas. Master's thesis, Department of Anthropology. The University of Texas at Austin.

Perttula, T. K

2006 A Study of the Buddy Jones Collection from Northeast Texas Caddo Sites. Spccial Publication No. 6. Friends of Northeast Texas Archaeology, Austin and Pittsburg.
2007 Seriation Proposed by Kleinschmidt (1982:Table 19) of Allen Phase and Frankston Phase Sites in the Upper Neches River Basin. Journal of Northeast Texas Archaeology 26:150-153.

Perttula, T. K., D. B. Kelley, D. E. Wilson, and B. M. Albert 2007 Final Research Design for Data Recovery Excavations al 41AN38, Anderson County, Texas. Coastal Environments, Inc. and Archeological \& Environmental Consultants, LLC. Baton Rouge and Austin.

Shafer, H. J.

1981 Archeological Investigations at the Attaway Site, Henderson County. Texas. Bulletin of the Texas Archeological Society 52:147-179. 